\title{
Academic Perfectionism among Adolescents: A Qualitative Study
}

\author{
Muhammad Ibrahim ${ }^{1} *$ and Cathy Sofhieanty Syamsuri ${ }^{2}$ \\ 1,2 Department of Psychology, Universitas Brawijaya, Malang, Indonesia \\ *E-mail: muhaibra@student.ub.ac.id
}

\begin{abstract}
In this post-millennial era, different generations have different values and ways of living. Millennials most notably tend to work less than older generations do. This degradation that happens in the millennial age motivated the researchers to acquire in-depth portrayal about how academic perfectionism works within the millennial age, particularly among adolescents. This study used the qualitative methodology and phenomenological approach. The study began with the distribution of standardized Hewitt and Flett's Multidimensional Perfectionism Scale (MPS) questionnaire to several high schools in Malang. The number of subjects was shortlisted and invited to participate in the further in-depth interview were two students who obtained the highest MPS scores and were aligned with the researchers' criteria. Prior to the interview, the researchers compiled several questions based on the Hewitt and Flett's (1991) perfectionism theory, which consists of three dimensions: Self-Oriented, Socially-Prescribed, and Other-Oriented. The researchers analyzed the data through Miles and Huberman data analysis procedures.
\end{abstract}

Keywords: Perfectionism, Adolescents, Academic Task

\section{Introduction}

The evolution of human life in the new millennium era happens vigorously and differs from the previous millennium. Unsurprisingly, individuals who come from previous generations have different values and ways of living compared to millennials. However, modern life has brought new challenges and results in millennials' tendency to work less than older generations do in some aspects (Pyoria \& Ojala, 2017). On the other hand, according to Howe and Strauss (as cited in Twenge, 2012), the augmentation of today's social life, makes adolescents who are considered to live in the millennial age strive to be the best in several areas such as academic, appearance, or even career. In this study, we only focus on perfectionism phenomenon that commonly happens within academic activities among adolescents. Essentially, adolescents who pursue high school education would desire to earn high academic grades and would strive for it.

According to Santrock (2007), adolescents are individuals aged 10-13 up to $18-22$ years old. This age range requires adolescents to pursue one of their developmental tasks in the field of education. Demands from adolescent developmental task result in parents' ambition for their children to earn good grades and demonstrate outstanding performance in academic tasks to pass the scores they have set as their standard. In addition, the existence of selfstandards in adolescents requires them to have set standards for themselves. However, sometimes the self-standards adolescents set on themselves are contradictory to their abilities.

This phenomenon in the science of Psychology is known as perfectionism. The term refers to an inner desire or the longing to establish and achieve higher standards and successes. According to Aditomo (2004), perfectionism is mostly found in students and individuals with an above average intellectual ability. Perfectionism is one of the many psychological variables that can affect adolescents' lives. A perfectionistic teenager might tend to suffer depression. This is due to the excessively high standards initiated by perfectionistic teenagers that are not aligned with their actual ability, which then creates the gap between one's ideal ego and the factual ego (Aditomo 2004). In addition to causing depression, perfectionism can also lead to negative traits such as narcissism, Machiavellianism, psychopathy, aggression, and poor social relationships that lead to the lack of prosocial behavior. The emergence of these traits is due to the demands of high expectations toward other people, also known as 'Other 
Oriented Perfectionism' (Smith, Sherry, Chen, Flett, \& Hewitt, 2016). Considering the fact that these traits develop in adolescents, they may well cause difficulties for teenagers in building relationships with friends.

The perfectionism phenomenon reaps a lot of concern in the field of Psychology that many scientists study the topic. According to Gunawita (2008), there is a correlation between perfectionism and academic procrastination. Furthermore, a study was conducted (Ratna, 2012) on perfectionism in gifted adolescents, with the results showing that perfectionism characteristics in gifted adolescents include setting excessively high standards, giving their best efforts to achieve perfect results, having low tolerance towards errors, paying attention to details, having confidence in self-ability, displaying anxiousness about making mistakes, intensively measuring between what is achieved and what should be achieved, having the tendency to respond towards errors or failures negatively, changing mood easily as a reaction of failures, blaming other people when they do not meet personal standards and expectations, and occupying intrinsic and extrinsic motivation to avoid failure. In this study, the researchers focus on the portrait of perfectionism in academic tasks among adolescents.

\section{Perfectionism}

Perfectionism, according to Hewitt and Flett (1991), is the attempt to not make mistakes and achieve perfection in every aspect of one's individual life. Huelsman (as cited in Ananda, 2013) defines perfectionism as the desire to achieve perfection, consisting of adaptive perfectionism derived from an individual's internal aspects as well as maladaptive perfectionism derived from an individual's external aspects. Thus perfectionism can be considered as a tendency or desire emerging from within or outside of the individual self to achieve high standards and achievements.

According to Adler (as cited in Aditomo, 2004), there are two types of perfectionism: 1) maladaptive perfectionism is when an individual sets an unrealistic standard toward themselves, and 2) adaptive perfectionism is the individual who sets a self-standard and achieves the said standard in accordance with their capabilities and limitations.

Perfectionism as it is defined in Hewitt and Flett's (1991) Multidimensional Perfectionism Scale (MPS) can be understood through three dimensions:

1) Self-Oriented, which is a personal component of perfectionism from an individual who creates high and unrealistic standards for performance and self- behavior, as well as a strong motivation to be perfect. A self-oriented perfectionist will spend many hours working and would still be unsatisfied with their results even though others might have given the acknowledgment for their results. Self- oriented perfectionism is associated with self-directed behavior, such as high levels of aspiration, frequent repetition of self-blame, anxiety, depression, and personality disorder (Hewitt \& Flett 1991)

2) Socially-Prescribed is the perfectionism that results from the formation of social environment due to individual beliefs regarding other people's unrealistic standards and perfectionistic motives against them (Hewitt \& Flett, 1991). This dimension is defined as the perception that others might have high expectations of themselves. Other people will be satisfied when a perfectionist can meet his or her expectations, and sometimes such external control is unrealized to the extent that it becomes an internalized criterion within a perfectionist (Gunawita, 2008).

3) Other-Oriented is the interpersonal dimension of perfectionism that involves the beliefs, hopes, and abilities of other people. This dimension can be interpreted as a belief and high expectations toward others. This dimension causes a person to set immensely unrealistic and strict standards in evaluating others. In addition, this dimension can also lead to hostility, authoritarianism, and dominance (Gunawita, 2008).

\section{Adolescents}

According to Santrock (2007), adolescents are individuals aged between 10-13 up to 18-22 years old who have experienced hormonal or puberty changes and other related developments that lead to independence. At the developmental stage of adolescence, individuals will experience several phases of change, including hormonal, physical, psychological, and social developments. Havighurst (1991) states that adolescents have several developmental tasks, such as: to attain a new pattern of more mature relationship; to achieve a social role in the society according to one's gender; to accept the state of physical organs on their body to be used 
effectively; to be socially responsible for behavior undertaken within the social context of a society; to prepare for a particular career economically; and to acquire a set of values and ethical systems as a code of conduct.

\section{Academic Tasks}

Academic tasks according to Santoso and Priatno (as cited in Anggraeni, 2015) is the obligation that must be done by students for their qualifications in a learning process. This task measures the degree to which students succeed in their learning by evaluating to what extent students master certain subjects. According to Solomon and Rothblum (as cited in Gunawinata, 2008), there are six areas of academic tasks: 1) Writing Task a task related to writing, such as writing reports, papers, and essays; 2) Learning - tasks that include the process of understanding, memorizing, and learning the subject matter to prepare for a test such as quiz, midterm exam, and final exam; 3) Reading Tasks - including reading a reference book, literature, or journals of research related to a particular academic task; 4) Administrative Performance Tasks - including administrative matters such as copying notes and filling the attendance list; 5) Attending Academic Meetings - including demands for attending labs, class lessons, and other academic meetings; 6) Overall Academic Performance - including individual performance in doing the given tasks thoroughly.

\section{Methods}

Participant Selection. Subjects for this study were selected through a purposive sampling technique using a criterion- $i$ sampling strategy. The purpose of this strategy was to identify participants by distributing a standardized Hewitt and Flett's Multidimensional Perfectionism Scale (MPS) questionnaire to 30 students from three different high schools in Malang. The researchers used the construct of perfectionism as defined by Hewitt and Flett (1991), which embraces three dimensions: Self- Oriented (having high expectation for one's performance), SociallyPrescribed (perceiving that others have high expectations for one's performance), and OtherOriented (having high expectations for others' performance). In this study, the criteria used for subject selection were: a) Individuals aged 10-13 to $18-22$, b) Considered to have perfectionism tendencies (as shown from their MPS score), and c) Showing evidence for their perfectionism tendencies in their academic achievements records.
After all MPS questionnaires were marked, the researchers started drafting those participants with the highest score on any subscale first and then proceeded to determine whether they met another standard. Participants who met these criteria were two adolescents pursuing high school education in Malang, both of whom passed the National Science Olympics/OSN and had other academic achievements. The shortlisted subjects who attained the final results that met the researcher's criteria were then enlisted to participate in a further in-depth interview.

Research Design. This study used a qualitative research method to acquire a deep portrait of what, how, and why a particular phenomenon happens within social context. According to Banister (as cited in Semedhi, 2015), qualitative research is an interpretive study of a specified issue or problem in which the researcher acts as a data-taking instrument. The approach that was used in this qualitative research was a phenomenological one. Frost (in as cited Semedhi, 2015) defines phenomenological study as a research that reveals details of personal life experiences to describe how people are making sense of their psychological and social world. This method was chosen to acquire an in-depth portrayal about how perfectionism in academic task happens among adolescents.

Instrument and Interview. The MultiDimensional Perfectionism Scale consists of three dimensions: Self-Oriented, SociallyPrescribed, and Other Oriented (Hewitt \& Flett, 1991). Self-Oriented is defined as individuals having high expectation of their own performance, Socially-Prescribed is defined as individuals perceiving that others have high expectations toward themselves, while OtherOriented is defined as individuals having high expectations toward others' performance. Each subscale of this questionnaire consists of 15 questions on a 7-point Likert scale.

The role of the researcher in this qualitative study is to maximize the interview process by building a good rapport with the subjects as a baseline of researcher - subject relationship. Thus, the researcher would be able to dig up necessary information for research data through interview session easily. As for the involvement of the researcher in this study, the researcher acted as a total researcher, in which both the researcher and subjects are fully aware of each other's role in the study. The interview technique consisted of indepth, semi-structured interview through open- 
ended questions. According to Seidman (as cited in Neumeister, 2009), in-depth interview involves asking open-ended questions designed for participants to reconstruct their experiences and to explore their meaning. This particular technique was chosen in order to gather data as deep as possible yet to not deviate from the research topic and to minimize bias by reducing the use of leading questions as well. In this study, data collection process from the subjects as resources were done more than once until the data acquired was saturated.

The main data resource in this study was derived from the subjects' answers during the interview process. Prior to the interview, the researcher compiled several questions based on the Hewitt and Flett's (1991) perfectionism theory, which consists of the three dimensions previously discussed, namely Self- Oriented, SociallyPrescribed, and Other-Oriented. This formulation of questions was done in order to obtain the right information that could be analyzed to figure out the significance of the topic of research, which is the portrait of perfectionism in academic tasks among adolescents.

Measurement. After the interview was conducted, the researchers transcribed the script verbatim and analyzed the data through procedures of Miles and Huberman data analysis. The steps of Miles and Huberman data analysis by hand began with data reduction, data display, and building conclusion (Miles \& Huberman, 1992). The data reduction process began with the editing and segmenting of the data, which was followed afterward by coding, marking, and related activities such finding themes, clusters, and patterns (Miles \& Huberman, 1992). Data display process consisted of organizing, compressing, and assembling information. While in the building conclusion process, the researcher followed the reduction and display of data in order to create a possible conclusion.

The verification of this qualitative research was mandatory to ensure the credibility of data (trustworthiness), to assure that the research that was conducted is valid, and to reduce the chance of misinterpretation. In this research, the researcher focused on using the level validity of trustworthiness (credibility), specifically the triangulation strategy, which includes the triangulation of time. Henceforth, to examine the legitimacy and validity of data resulting from the interviews, the interviews were done more than once until the data acquired was saturated. Nevertheless, in qualitative research, the level of trustworthiness can replace interval validity and data legitimacy.

Procedure. The study began with the distribution of standardized Hewitt and Flett's Multidimensional Perfectionism Scale (MPS) questionnaires to several high schools in Malang. After all of the MPS questionnaires were scored, the researchers started drafting those participants with the highest score on any subscale first and then proceeded to determine whether they had any academic achievements records. Shortlisted subjects who attained the final results aligned to the researcher's criteria were then invited to participate in a further in-depth interview.

The interview process was conducted by using semi-structured and in-depth interview through open-ended questions. After the interview was conducted, the researchers transcribed the script verbatim and analyzed the data through procedures of Miles and Huberman data analysis. According to Miles and Huberman (1992), the data analysis technique consists of three stages: 1) Data reduction by sharpening, classifying, directing, removing the unnecessary, and organizing data; 2) Data presentation by compiling, sorting, and categorizing information that would alternatively be used as a material of conclusion; and 3) Drawing conclusions.

\section{Results}

\section{Portraits of Academic Perfectionism}

According to the in-depth interviews conducted with the subjects, several results were obtained regarding the origins of their academic perfectionism behavior.

\section{Self Oriented}

According to the interview, resulting in Self Oriented dimension shows that the first subject (FK) sets a high standard for his academic performance and expects maximum final results, as can be seen from the information given by the subject below:

"Basically it's quite similar. I always struggle to get at least 9 on the final score. And I always finish my individual assignment at home, once I meet any difficulties, I can access the internet, open the textbook, ask for help from my parent and friend, or do anything that helps me to prevent a bad score and failing" (FK/CA/W2/562)

FK was motivated to carry out the highest achievements by striving to accomplish well- established goals and constantly 
seeking solutions for any problems he encountered. This is evident from this subject's description:

"Not really, I constantly put maximum effort on OSN, at least I have to pass the semifinal round. However, the last OSN was really hard and I couldn't make it." (FK/CA/W2/35)

"I was quite sad when I have put in the long effort but I can't make it. I was thinking really hard and the next day I have solved it. I try to use my friend's launcher and it works." (FK/CA/W2/92)

Moreover, our second subject (LC) also sets a high standard for himself by determining his minimum grade, which is beyond the passing grade. LC has own criteria for success as well:

"In terms of minimum score, I try to get 9 on average and exceed 8. Even though 8 was the passing grade, I try to exceed it." (LC/CAIB/W2/158)

"My criteria in academic success was to acquire good score in the class, by not only memorizing the material but also fully understanding them." (LC/CA- IB/W2/154)

LC has motivations to yield achievements by studying consistently and not repeating mistakes that were done in the past:

"The last step was, I study consistently. Once I face any difficulties, I only try to study by myself and read the book as much as I can." (LC/CA$\mathrm{IB} / \mathrm{W} 1 / 439)$

"Hmmm, when I've finished the exam and I realize that I've made a mistake, I feel regretful. But I promise myself to not repeat the same mistakes in the future." (LC/CA-IB/W1/488)

Based on the data above, it could be summarized that adolescents with academic perfectionism voluntarily have self-realization toward their responsibilities. This selfrealization makes them realize that they have to achieve the best result by setting the highest standards and that they have to study consistently to yield an achievement. Additionally, individuals with academic perfectionism also realize that they have to learn from their mistake and not repeat mistakes twice, often by seeking solutions for the problems they encounter.

\section{Socially Prescribed}

The result of this second dimension in subject FK shows the presence of a high standard of requirement prescribed by other people, such as parents, teachers, and school mates:

"My parents, my friends, my economics' teacher as well.” (FK/CA/W2/350)

While LC acquires a high standard of expectation from his parents:

"My parents always compare me to other friends who have succeeded and are accepted to sophisticated schools." (LC/CA-IB/W1/306)

"Both of my parents encourage me and push me at the same time." (LC/CA-IB/W1/352)

In dealing with the parents' high requirements, LC feels burdened and realizes that such expectations have a great influence on him:

"If I have to force myself to master every aspect, I'll feel really burdened. But if I am only expected to master one aspect that I love, I'll really enjoy it." (LC/CA-IB/W1/375)

"If they do not put any pressure on me, I might never realize and just undergo anything as it is. But their expectation has succeeded in exerting a great influence on me." (LC/CA-IB/W2/482)

According to the data, adolescents' social environment and significant others contributed to their perfectionism development. Adolescents with academic perfectionism tend to get high standards from their surroundings, which then become a powerful influence in their life, even though sometimes it makes them feel burdened.

\section{Other Oriented}

In the third dimension, FK did not mention his demand and expectations towards other people. FK said that when working in groups, he always trusts the team members and the division of tasks in a group, as well as having optimism in his teammates' work performances:

"Exactly. I believed they can do it, but the thing was, our group only consisted of two males and the other were females. It was not easy to make a launcher, and these conditions made it worse." (FK/CA/W2/79)

"Yes. Because I was really optimistic that our team would get a good score, I believe that the teacher won'tgive us score below the passing grade."

(FK/CA/W2/211)

"Yes, I believe that our group division is reliable." 
(FK/CA/W2/194)

Furthermore, LC also did not insist on high expectations towards other people's performances. This is reflected through LC's trust on others, low level of demand, and the presence of job division:

"Once the group is established, I have to 100\% trust them. I believe that in a group, we have to trust each other." (LC/CA-IB/W2/376)

"We will share the responsibility for a group assignment. I will ask them first regarding their interest, their plan, and their job desc." (LC/CAIB/W2/306)

"I never force them. I believe that everyone has their own characteristic, interest, and talent that can not be changed. It depends on them; I always give them freedom." (LC/CA-IB/W2/296)

In sum, adolescents with academic perfectionism tend to not put any high demand or expectation toward anyone. Once they meet any obstacle in the process of achieving the goals, they will rely on themselves to solve it.

Table 1.

Image of Academic Perfectionism

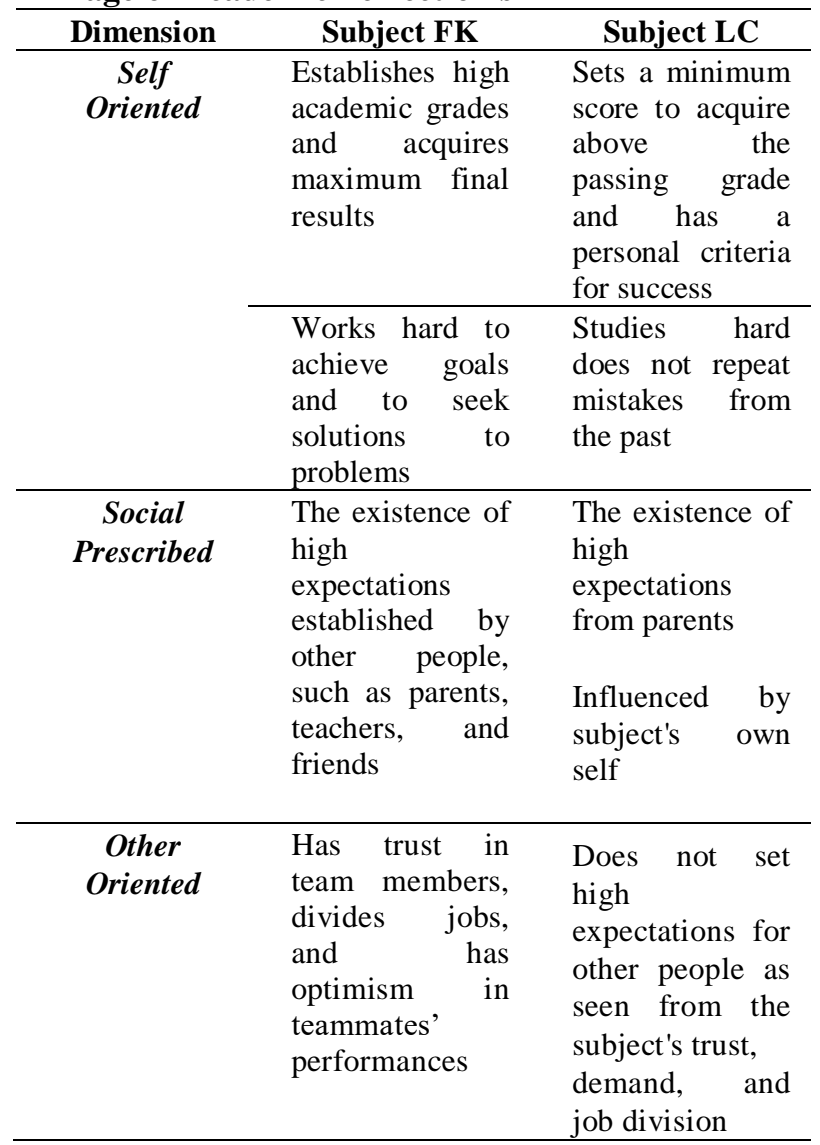

\section{Discussion \& Conclusion}

Based on this research, academic perfectionists present several characteristics in the Self Oriented dimension, such as 1) Establishing very high standards and the criteria for success, which was observable from the desire of the subjects to earn maximum scores above the passing grade. According to Ratna (2012), this characteristic is the main distinction of a perfectionist. In addition, Rim (as cited in Ratna, 2012) also explains that the setting of high standards can occur in several ways, one of which is portrayed in academic achievements; 2) Having a strong desire to achieve goals, which occurs because the high standards set by perfectionists urge them to consistently give their best and to be in control of their environment, therefore assuring that everything works in accordance with the established standards (Ratna, 2012); 3) Trying to not repeat mistakes, which as mentioned by Ramsey and Ramsey (as cited in Ratna, 2012), a perfectionist fears failure because of the established standard.

In the Socially Prescribed dimension, the image of perfectionism in academic tasks is the existence of values, expectations, and standards derived from the environment, particularly parents, friends, and teachers. According to Flett and Hewitt (1995), perfectionism can grow in families engaged in an authoritarian parenting style. In addition, one of the reasons that a person becomes a perfectionist is associated with the parent's trait. According to Soenens (as cited in Azizi, 2011) a perfectionist parent will set a high and exaggerated expectation regarding mistakes children make. According to Dix (as cited in Azizi, 2011), this is a result of perfectionist parents who impose their personal standards and norms on their children. Moreover, in the Socially Prescribed dimension, individuals may feel burdened. This is due to the external pressure that requires someone to be the best. Based on the results of Naumann's study (2014), it was stated that most Asian children consider their parents' expectations to be very high, which causes depression and stress. As a matter of fact, high expectations from parents are not legitimately bad, but when parents criticize their children too much, it will increase the risk of child depression. It can further be observed that expectations from the environment affect academic achievement. According to Mc.Clelland (as cited in Sugianto, n.d.), there are several environmental factors that can generate a person's achievement, for instance the existence of norms or standards that must be achieved, 
therefore encouraging individuals to do their best, to set a standard of excellence that leads to competition, and to pursue challenging tasks.

In the Other Oriented dimension, the image of perfectionism in an academic task is the absence of high expectation towards other people, or in other words, a perfectionist believes in the performance of others. In their given statements, both subjects stated that they trust their team members prior to the presence of job divisions based on each team member's abilities. The results of this study differ from the statements expressed by Hewitt and Flett (1991) that the Other Oriented dimension will cause a person to strictly evaluate the work of others by demanding that other people meet their unrealistic expectations. It is also different from Adderholdt and Goldberg's (as cited in Ratna, 2012) view that a perfectionist is unable to trust other people to perform work considering the belief a perfectionist holds that other people cannot work as well as themselves, which leads to the tendency to perform the tasks themselves. The possible explanation that could support this particular result of the current research is the diffusion of responsibility theory. According to the theory, the unclear division of tasks in a group as well as the increasing number of people involved in the task would result in the decline of responsibility each person has in the task assigned (Baron \& Byrne, 2000). In this manner, the presence of precise job division would cause perfectionists to reduce their demands and expectations of others that are too high. In addition, differences in the results of this study may be caused by cultural bias. Most studies of perfectionism were conducted in western countries, whereas culture contributes a large part to the formation of psychological concepts. Kim and Park (as cited in Anggoro, 2010) state that culture has a central role in a person's perception of social phenomenon.

Furthermore, further research needs to consider using both quantitative and qualitative methods in order to gain a more comprehensive result. This combination method is expected to be able to verify and triangulate the portrait of academic perfectionism. Moreover, further research needs to consider the use of more complex dimensions to gain a more fruitful and broader portrait of academic perfectionism.

Conclusions. This research yielded a finding on the image of perfectionism among adolescents in academic tasks. Consequently, the portrait of perfectionism in adolescents on academic tasks demonstrates the following: the establishment of excessively high standards and personal criteria of success; the strong desire to achieve goals; the demand to not repeat previous errors; the existence of values, expectations, and standards derived from the environment, particularly parents, friends, and teachers; the bearing in which a perfectionist would feel burdened; the impacts of an environment's expectations on academic performances; and the absence of high expectations of other people due to a perfectionist's trust in the performance of others.

This study has several limitations that need to be tackled in further research. The first limitation found in this research is the few number of subjects. In particular, a wider distribution of MPS questionnaires in the participation selection process is needed. Additionally, more empirical studies among adolescents in middle school and college levels are needed to determine whether there are any differences in perfectionism across age groups. The findings of this research are beneficial to parents and the society for facing academically perfectionist adolescents. Moreover, the results of this study could add to existing scientific literature on perfectionism.

\section{References}

Aditomo, A., \& Retnowati, S. (2004). Perfeksionisme, Harga Diri, dan Kecenderungan Depresi pada Remaja Akhir. Jurnal Psikologi, 1, 1-14.

Ananda, N. Y., \& Mastuti, E. (2013). Pengaruh Perfeksionisme terhadap Prokrastinasi Akademik pada Siswa Program Akselerasi. Jurnal Psikologi Pendidikan dan Perkembangan, 2(2), 226-231.

Anggoro, W. J., \& Wahyu, W. (2010). Konstruksi dan Identifikasi Properti Psikometris Instrumen Pengukuran Kebahagiaan Berbasis Pendekatan Indigenous Psychology: Studi Multitrait-Multimethod. Jurnal Psikologi Universitas Gadjah Mada, 37, 176-188.

Anggraeni, P. (2015). Hubungan Antara Persepsi Terhadap Tugas Akademik dan Atraksi Interpersonal Siswa Terhadap Guru dengan Regulasi Diri Siswa Program Olimpiade Sains Nasional (OSN) SMA Negeri 10 Samarinda. E-Journal Psikologi Fisip Unmul, 3(2), 504516.

Azizi, K., \& Besharat, M. A. (2011). The Relationship between Parental Perfectionism and Parenting Style. Procedia Social and Behavioral Science, 15, 1484-1487.

Badan Pengembang dan Pembinaan Bahasa Kemendikbud RI. (2016). Kamus Besar Bahasa Indonesia Edisi ke-5. Jakarta: Gramedia Pustaka.

Baron, R. A., \& Byrne, D. (2000). Social 
Psychology (9th edition). Massachusetts: A Pearson Education Company.

Flett, G. L., Hewitt, P. L., \& Singer, A. (1995). Perfectionism and Parental Authority styles: Individual psychology. Journal of Adlerian Theory, Research, and Practice, 5, 50-60.

Gunawita, V. A. R., \& Lasmono, H. K. (2008). Perfeksionisme, Prokrastinasi Akademik, dan Penyelesaian Skripsi Mahasiswa. Anima, Indonesian Psychological Journal, 23(3), 256276.

Havighurst, R. J. (1985). Human Development and Education.

Surabaya: Sinar Wijaya.

Hewitt, P. L., \& Flett, G. L. (1991). Perfectionism in the Self and Social Contexts: Conceptualization, Assessment, and Association with Psychopathology. Journal of Personality and Social Psychology, 60, 456470.

Miles, M. B., \& Huberman,

A. M. (1992). Analisis Data Kualitatif. Jakarta: UI Press

Naumann, L. P., Guillaume, E. M., \& Funder, D. C. (2014). The Correlates of High Parental Academic Expectations: an Asian-latino Comparison. Journal of Cross-Cultural Psychology, 87(8), 515-520.

Neumeister, K. L., Williams, K. K., \& Cross, T. L. (2009). Gifted High-School Students' Perspectives on the Development of Perfectionism. Rooper Review, 31. 198- 206.

Pyoria, P., Ojala, S., \& Saari, T. (2017). The Millenial Generation: A New Breed or Labour?. SAGE Open. 1-14.

Ratna, P. T., \& Widayat, I. W. (2012). Perfeksionisme pada Remaja Gifted (Studi Kasus pada Peserta Didik Kelas Akselerasi di SMAN 5 Surabaya). Jurnal Insan, 14(3), 203 210.

Santrock, J. W. (2007). Remaja Edisi 11 Jilid 1. Jakarta: Erlangga.

Semedhi, B. P. (2015). Resiliensi Pengungsi Konflik Sampang.

Jurnal Mediapsi, 1(1), 51-58.

Smith, M. M., Sherry, S. B., Chen, S., Flett, G. L., \& Hewitt, P. L. (2016). Perfectionism and Narcissism: A meta-analytic review. Journal of Personality Research, 64, 90-101.

Sugiyanto. (n. d.). Pentingnya Motivasi Dalam Mencapai Keberhasilan Akademik BtdjVAhWIsI8KHTAcAxgQFggqMAA\&url= http $\% 3 \mathrm{~A} \%$

2F\% 2Fstaff.uny.ac.id $\% 2$ Fsites $\% 2$ Fdefault $\% 2 \mathrm{~F}$

files $\% 2 \mathrm{Fp}$ enelitian $\% 2 \mathrm{Fsugiyanto-}$ mpd\%2Fpentingnya-motivasi- berprestasidalam-mencapai-keberhasilan-akademiksiswa.pdf\&usg=AFQjCNHiXRbwmOEfmw1 NXp9B93m 6fF2v-g
Twenge, J. M., Campbell, W. K., \& Freeman, E. C. (2012). Generational Differences in Young Adults' Life Goals, Concern of Others, and Civic Orientation. Journal of Personality and Social Psychology, 102(5). 1045-1062. 